\title{
Incidencia de la fuente de fósforo y de la presencia de moléculas autoinductoras sobre la capacidad solubilizadora de aislamientos bacterianos nativos de la Región Semiárida Pampeana.
}

Soncini, Daiana L.*; García, Patricia; Lucero, Cinthia; Lorda, Graciela; Castaño, Rosana C. Filiación: Facultad de Ciencias Exactas y Naturales. Universidad Nacional de La Pampa.

*E-mail: daianasoncini@hotmail.com.ar

Introducción: El fósforo es uno de los nutrientes considerados esenciales para el crecimiento y desarrollo de las plantas. En la región semiárida pampeana hay zonas que presentan niveles críticos de contenidos de fósforo, el que predomina bajo formas insolubles, no asimilable para las plantas. Por otra parte, se ha estimado que hasta un $75 \%$ de los fertilizantes fosforados aplicados como fertilizantes químicos pueden ser también inmovilizados en el suelo debido a la precipitación de la fase mineral y en consecuencia tampoco pueden ser aprovechados por los cultivos. Por lo tanto la solubilización de las distintas rocas fosfatadas y de otras fuentes de fósforo inorgánico por parte de microorganismos del suelo, constituye una alternativa fundamental para incrementar la disponibilidad de este nutriente de una manera ecológica, beneficiosa para el enriquecimiento de los suelos y el rendimiento de los cultivos. Un considerable número de especies bacterianas, pertenecientes al grupo bacterias promotoras del crecimiento vegetal ("plant growth promoting rhizobacteria" o PGPR), la mayoría asociadas con la rizósfera de las plantas, son capaces de llevar a cabo este procesos de solublización. En los ambientes naturales existen diversos géneros bacterianos que conviven y utilizan numerosos tipos de moléculas "señal" para comunicarse e interactuar, según el fenómeno conocido como quorum sensing. Los cambios en el comportamiento de poblaciones bacterianas resultan de la interacción entre células vecinas, por medio de la activación de genes específicos en respuesta a estas moléculas señal, que en bacterias Gram negativas, la más ampliamente descripta, corresponde al tipo acil homoserina lactonas (AHLs). En este trabajo se evaluaron aislamientos de bacterias solubilizadoras de fósforo, nativas de la Región Semiárida Pampeana, respecto de su capacidad de solubilización frente a diferentes sustratos fosforados y a la presencia de moléculas señal del tipo AHLs, homólogas y heterólogas.

Materiales y métodos: Para evaluar la incidencia de fuentes fosforadas sobre la capacidad solubilizadora de fósforo, se desarrollaron cultivos líquidos de los diferentes aislamientos en estudio en medio de cultivo NBRIP, al cual se le reemplazó la fuente de fósforo (fosfato dibásico de calcio) por fosfato tricálcico anhidro o fosfato de aluminio, según los diferentes tratamientos. A fin de analizar el efecto de AHLs se desarrollaron cultivos líquidos de las bacterias en medio NBRIP previamente suplementado con extractos de AHL provenientes de la misma especie microbiana (AHLs homólogas) y de otras especies bacterianas (AHL heterólogas). En todos los casos, las bacterias se incubaron a $28^{\circ} \mathrm{C}$, en agitación y a las $48 \mathrm{~h}$ de desarrollo, y se determinó la capacidad solubilizadora de fosfato. La cuantificación de la capacidad de solubilización de fósforo en medio líquido, se llevó a cabo por medio de la técnica de Fiske y Subbarow modificada. Los resultados fueron analizados mediante ANOVA de un factor. La comparación de medias se realizó mediante el test de DMS, con un nivel de significación del 0,05

Resultados: Los aislamientos bacterianos estudiados mostraron ser eficientes en cuanto a la capacidad de solubilizar fósforo a partir de las diferentes fuentes insolubles de este mineral, alcanzando valores de entre $40 \mathrm{ppm}$ a $60 \mathrm{ppm}$ de fósforo soluble, concentraciones que de lograrse en condiciones naturales sería un importante aporte de este nutriente para los cultivos. Cabe destacar que en todos los casos el aumento de fósforo disponible fue acompañado con una disminución del $\mathrm{pH}$. Respecto de los estudios realizados sobre la incidencia de moléculas AHLs, no se encontraron diferencias en la actividad solubilizadora de las bacterias en presencia de éstas moléculas. En esta serie de ensayos, los valores de $\mathrm{pH}$ prácticamente no variaron frente a los diferentes tratamientos.

Conclusiones:Estos resultados se consideran relevantes dado que muestran eficiencia y versatilidad por parte de los aislamientos bacterianos respecto del sustrato fosforado a solubilizar, condición que como ya se mencionó, representa los diferentes tipos de suelos en los que estos microorganismos podrían actuar. Por otra parte, se puede inferir que la capacidad solubilizadora de P no está influenciada por el fenómeno quorum sensing. Los resultados obtenidos exponen una alternativa al uso de fertilizantes químicos, y ofrecen la posibilidad de utilizar estos microorganismos en la formulación de biofertilizantes regionales, dado que en condiciones de campo, las cepas aisladas poseen además la ventaja de la adaptación a las condiciones físico químicas de la región respecto de cepas introducidas, considerando que los mecanismos y estrategias de colonización representan un punto clave en este tipo de interacciones. 